\title{
Influence of traumatic acid on growth and metabolism of Chlorella vulgaris under conditions of salt stress
}

\author{
Anna Pietryczuk • Iwona Biziewska • \\ Monika Imierska $\cdot$ Romuald Czerpak
}

Received: 3 May 2013/ Accepted: 16 November 2013/Published online: 28 November 2013

(c) The Author(s) 2013. This article is published with open access at Springerlink.com

\begin{abstract}
The aim of this work was to study the role of traumatic acid (TA) in the adaptation of green algae Chlorella vulgaris Beijerinck to salt stress. In order to achieve this aim, studies were conducted concerning the influence of exogenous TA at a concentration of $10^{-5} \mathrm{M}$ combined with sodium chloride $(\mathrm{NaCl})$ at various concentrations $\left(10^{-7}-10^{-4} \mathrm{M}\right)$, on the growth of $C$. vulgaris and the levels of basic biochemical parameters, such as chlorophylls $a$ and $b$, monosaccharides, cell proteins and the activity of superoxide dismutase enzyme. The studies carried out demonstrated that TA eliminated the negative effects of $\mathrm{NaCl}$ at all test concentrations and also increased the content of carotenoids, monosaccharides and cell proteins.
\end{abstract}

Keywords Traumatic acid · Salt stress · Chlorophylls $\cdot$ Monosaccharides · Proteins .

Superoxide dismutase

\section{Introduction}

Plants growing in natural conditions are constantly exposed to various stresses modifying the intensity or disturbing the course of life processes, causing temporary or irreparable destabilization of the plant organism. The activity of such

\footnotetext{
A. Pietryczuk $(\square)$

Department of Hydrobiology, Institute of Biology, University of Białystok, Świerkowa 20B, 15-950 Białystok, Poland

e-mail: annapiet@uwb.edu.pl

I. Biziewska $\cdot$ M. Imierska $\cdot$ R. Czerpak

Department of Plant Biochemistry and Toxicology, Institute

of Biology, University of Białystok, Świerkowa 20B,

15-950 Białystok, Poland
}

harmful factors may lead to inhibition of growth and development of the plant or even to its death (Shulaev et al. 2008).

Recently the salinity of soils has been a more and more serious problem. It is commonly known that salt restricts the growth of a plant more than any other toxic substance. The impact of soil salinity on plants can vary depending on the kind of salt, its concentration, the kind of cultivated plant, the condition of the environment, and a number of other concominants (Zhu 2001a, b). However, most plant species are sensitive even to relatively slight salinity, contributing to lessening the availability of water, thus lowering its potential in the soil solution. What is more, an excess of these ions, especially $\mathrm{Na}^{+}$and $\mathrm{Cl}^{-}$, disturbs ion management in plant cells and can affect oxidative stress (Zhu 2001a; Xiong and Zhu 2001; Tester and Davenport 2003; Wang et al. 2003). The salinity of soils and the irrigation of fields with partly desalinated seawater have very serious effects, causing the loss of farmlands which would have been very fertile. Lands covered with salinated soils occur on every continent; particularly numerously in deserts and steppe regions. Excessive use of artificial fertilizers and crop protection chemicals, as well as using large quantities of salt for clearing snow from roads, contribute to an increased accumulation of ions in soils and plants (Siyal et al. 2002; Zhu 2003).

Plants have, however, have achieved great success in adaptating to adverse conditions. They have developed two survival strategies: preventing or delaying the activity of stress factors in cells, as well as tolerating the stressor. The first strategy is the formation of various protection methods to prevent upsetting thermodynamic equilibrium by a given stressor. This is achieved by adjusting the plant's own life cycle to seasonally changing environmental conditions, or by physiological adjustment allowing for protection of a 
cell or the whole organism from the stressor. The other strategy is tolerating the effects of stressor activity. Tolerance also means initiating alternative metabolic routes and prevention of denaturation of proteins or nucleic acids (Bohnert and Shvelev 1998; Pareek et al. 2011).

Phytohormones are structurally simple organic compounds created in small quantities in different parts of the plant. One characteristic of phytohormones is a pleiotropic effect, where the same compound induces different physiological responses in separate target cells ( $\mathrm{Li}$ et al. 1996). Apart from phytohormones, other organic compounds called plant growth and development regulators, participate in regulation of plant metabolism. One such regulator is traumatic acid (TA): a plant wound hormone. It stimulates cell divisions and elongation growth in the wounded area of a plant, and formation of a callus (Sivasankar et al. 2000; Howe and Schilmiller 2002). TA and its aldehydic form (traumatin) belong to derivatives of unsaturated fatty acids. They are intensively synthesized by plants as a response to wounding, usually that caused by phytophages and pathogens. Numerous studies have proven that traumatin and related compounds occur quite commonly in the world of vascular plants and lower organisms, such as fungi and algae, and cooperate with other phytohormones in the stimulation of growth, adaptation to stresses, and regulation of many physiological and metabolic processes (Siedow 1991; Pietryczuk and Czerpak 2006; Pietryczuk et al. 2008)

Many studies concerning plant reactions to salt stress have been carried out to date. Until now, however, no studies have been performed regarding the impact of TA on plants subjected to salt stress. Therefore, research was conducted as part of work on monitoring the relations between adverse environmental conditions-salt stressand the activity of TA. A unicellular alga, Chlorella vulgaris, was analysed in two variants: first, establishing what changes in plant parameters would occur under the influence of $\mathrm{NaCl}$, and then, exposing the plant to $\mathrm{NaCl}$ combined with TA. The studies presented in this work were performed to determine whether TA can eliminate the negative effects of salt stress.

\section{Experimental procedures}

Plant material and growth conditions

C. vulgaris culture was sourced from the Department of Plant Biochemistry and Toxicology collection at the University of Bialystok (Poland). Microalgae were cultivated in stable conditions; humidity $45( \pm 5) \%$ and temperature $25( \pm 1){ }^{\circ} \mathrm{C}$. Illumination was supplied over a 16 -h photoperiod (8-h dark period) by a bank of fluorescent lights, yielding a photon flux density of $50 \mu \mathrm{mol} \mathrm{m}{ }^{-2} \mathrm{~s}^{-1}$ of photosynthetically active radiation (PAR) at the surface of the tubes. PAR was measured with an FF-01 phytophotometer (SOMOPAN, Poland). Permanent synchronous growth was established according to the method of Pirson and Lorenzen (1966). The culture medium used was modified Knop medium with the following components: $0.5 \mathrm{~g} \mathrm{KNO}_{3}, 0.5 \mathrm{~g} \mathrm{Ca}\left(\mathrm{NO}_{3}\right)_{2} \cdot 4 \mathrm{H}_{2} \mathrm{O}, 0.2 \mathrm{~g} \mathrm{KH}_{2} \mathrm{PO}_{4}, 0.15 \mathrm{~g}$ $\mathrm{MgSO}_{4} \cdot 7 \mathrm{H}_{2} \mathrm{O}, 0.01 \mathrm{~g} \mathrm{FeCl}_{3} \cdot 6 \mathrm{H}_{2} \mathrm{O}, 3 \mathrm{mg} \mathrm{H} \mathrm{H}_{3} \mathrm{BO}_{3}, 2 \mathrm{mg}$ $\mathrm{MnCl}_{2} \cdot 4 \mathrm{H}_{2} \mathrm{O}, 0.3 \mathrm{mg} \quad \mathrm{NH}_{4} \mathrm{VO}_{3}, 0.2 \mathrm{mg} \mathrm{ZnSO}_{4} \cdot 7 \mathrm{H}_{2} \mathrm{O}$, $0.1 \mathrm{mg}\left(\mathrm{NH}_{4}\right)_{6} \mathrm{Mo}_{7} \mathrm{O}_{24} \cdot 7 \mathrm{H}_{2} \mathrm{O}$ per litre of distilled water. The culture medium was sterilized by autoclaving at $125{ }^{\circ} \mathrm{C}$ for $25 \mathrm{~min}$. Besides this, glassware and bacteriological stoppers were sterilized in a thermal chamber at $105^{\circ} \mathrm{C}$ for $4 \mathrm{~h}$. The $\mathrm{pH}$ of the medium was stable at $6.80( \pm 0.1)$. Algae were cultured in Erlenmeyer flasks containing $250 \mathrm{~mL}$ of medium. The culture from which the inoculum was taken was in logarithmic growth phase.

In the present work, the effects of $\mathrm{NaCl}$ applied in a concentration range $10^{-7}-10^{-4} \mathrm{M}$ and TA at concentration of $10^{-5} \mathrm{M}$ were analyzed. Appropriate amounts of $\mathrm{NaCl}$ (Sigma-Aldrich Co., USA) were dissolved in distilled water, and added in correct concentrations to Erlenmeyer flasks with Knop medium, algal suspension and TA $\left(10^{-5} \mathrm{M}\right)$. Cell number and proteins, monosaccharides as well as photosynthetic pigment level in response to TA and $\mathrm{NaCl}$ were analyzed. The cell number and biochemical parameters were determined on the first, second and third days of cultivation. Cultures were conducted in four replicates.

\section{Determination of cell number}

The number of $C$. vulgaris cells was determined by direct counts of cells in the growth medium using a Bürker chamber.

\section{Determination of proteins}

The concentration of proteins was determined spectrophotometrically according to Lowry et al. (1951) using Folin phenol reagent with a protein kit calibrated with bovine serum albumin as the standard. The absorbance of the extracts was measured with a Shimadzu UV-Vis 1201 spectrophotometer (Japan).

\section{Determination of monosaccharides}

The concentration of monosaccharides was determined spectrophotometrically according to Somogyi (1954) using an arsenomolybdate reagent. At first $10 \mathrm{ml}$ subsamples of the algal culture were collected by centrifugation. After centrifugation the monosaccharides were extracted in 
ethanol for $24 \mathrm{~h}$. The absorbance was measured with a Shimadzu UV-Vis 1201 spectrophotometer (Japan).

Determination of photosynthetic pigments

The content of photosynthetic pigments (chlorophyll $a$ and $b$, carotenoids) followed homogenization of fresh C. vulgaris in $99.9 \%$ methanol at $70{ }^{\circ} \mathrm{C}$ for $30 \mathrm{~min}$ (Wellburn 1994). The absorbance of the extract was measured with a Shimadzu UV-Vis 1201 spectrophotometer (Japan) at 652.4 and $665.2 \mathrm{~nm}$ for chlorophylls $a$ and $b$ and at $470.0 \mathrm{~nm}$ for carotenoids. The amounts of photosynthetic pigments present in the methanol extract were calculated according to equations by Wellburn.

Determination of SOD activity

For the extraction of superoxide dismutase (SOD), a fresh sample of $C$. vulgaris was passed through paper filter under pressure and was homogenized using liquid nitrogen and subsequently a lysis buffer containing $0.1 \mathrm{M}$ phosphate buffer (pH 7.8), $3 \mathrm{mM} \mathrm{MgSO}$, $1 \mathrm{mM}$ dithiotreitol (DTT) and $3 \mathrm{mM}$ EDTA. The homogenate was centrifuged at $12,000 \mathrm{G}$ for $10 \mathrm{~min}$ and the resulting supernatant was used to determine enzyme activity. SOD (EC 1.15.1.1) activity was measured based on the inhibition of the photochemical reduction of nitroblue tetrazolium (NBT) according to Beauchamp and Fridovich (1971). The reaction mixture consisted of $0.1 \mathrm{M}$ phosphate buffer $(\mathrm{pH}=7.8,2.2 \mathrm{ml})$, $0.156 \mathrm{mM}$ riboflavin $(0.25 \mathrm{ml}), 0.156 \mathrm{mM}$ methionine $(0.25 \mathrm{ml}), 0.756 \mathrm{mM}$ NBT $(0.25 \mathrm{ml})$ and enzymatic extract $(50 \mu \mathrm{l})$. Samples were incubated for $20 \mathrm{~min}$ at room temperature. The absorbance of the extracts was measured spectrophotometrically at $560 \mathrm{~nm}$. One unit of SOD activity was defined as the enzyme concentration required to inhibit the reduction of NBT by $50 \%$.

Replication and statistical analysis

Each treatment consisted of four replicates and each experiment was carried out on at least two different occasions. The Minitab statistical package was used to carry out one-way ANOVA analysis. The Student's $t$ test was used to estimate the difference between means at a $5 \%$ level of significance.

\section{Results}

The conducted analyses included a study of the influence of (1) $\mathrm{NaCl}$ in a concentration range from $10^{-7}$ to $10^{-4} \mathrm{M}$ and (2) $\mathrm{NaCl}\left(10^{-7}\right.$ to $\left.10^{-4} \mathrm{M}\right)$ combined with exogenously applied TA at $10^{-5} \mathrm{M}$, on $C$. vulgaris. Changes in the

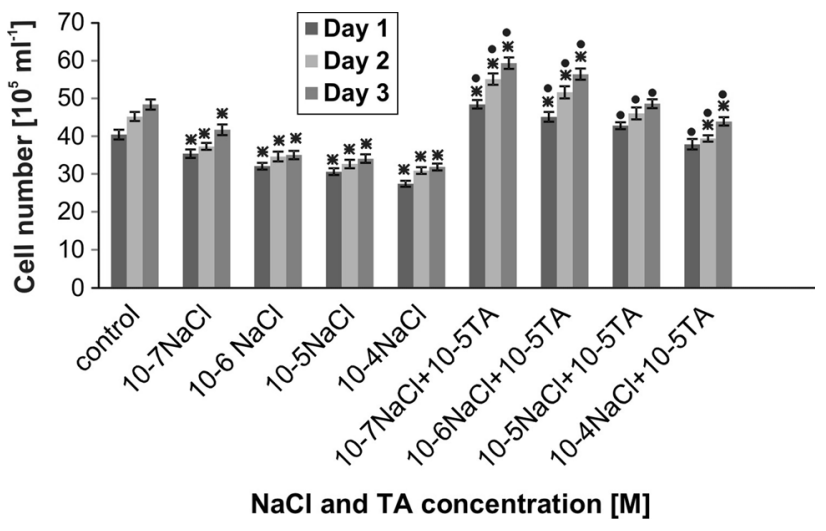

Fig. 1 The effect of traumatic acid $\left(10^{-5} \mathrm{M}\right)$ on cell number in $C$. vulgaris, treated with sodium chloride $\left(10^{-7}-10^{-4} \mathrm{M}\right)$. Data are the means of four independent experiments \pm SE. Asterisk indicates statistically different values compared to the control, filled circle indicates statistically significant differences between treatment with $\mathrm{NaCl}$ and the combined treatment $(\mathrm{NaCl}$ and $\mathrm{TA})$

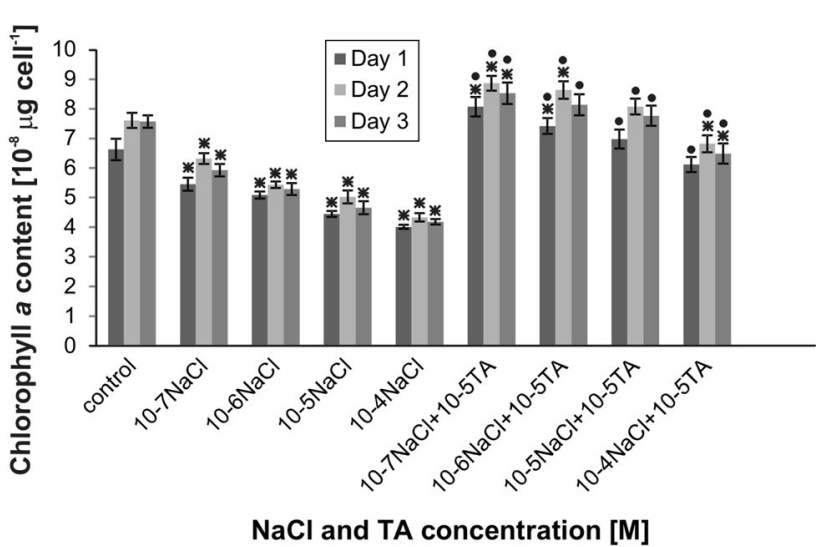

Fig. 2 The effect of traumatic acid $\left(10^{-5} \mathrm{M}\right)$ on chlorophyll $a$ content in $C$. vulgaris, treated with sodium chloride $\left(10^{-7}-10^{-4} \mathrm{M}\right)$. Data are the means of four independent experiments \pm SE. Asterisk indicates statistically different values compared to the control, filled circle indicates statistically significant differences between treatment with $\mathrm{NaCl}$ and the combined treatment $(\mathrm{NaCl}$ and $\mathrm{TA})$

number of algae cells, and the content of chlorophylls $a$ and $b$, carotenoids, cell proteins and SOD activity in C. vulgaris cells were recorded.

The results of the studies indicate the stimulating effect of TA with an increase in the number of $C$. vulgaris cells in cultures after exposure to salt stress (Fig. 1). Cultures treated with $\mathrm{NaCl}$ alone (without the addition of TA) displayed a decrease of the number of cells with the increase of salt concentration. Phytotoxic activity of salt stress was particularly visible on the third day of the culture at $10^{-4} \mathrm{M} \mathrm{NaCl}$, and led to a decrease in the number of cells by $34.9 \%$ compared to the control culture. The presence of TA in cultures exposed to all test concentrations of $\mathrm{NaCl}$, inhibited the negative influence of salt stress on the number 


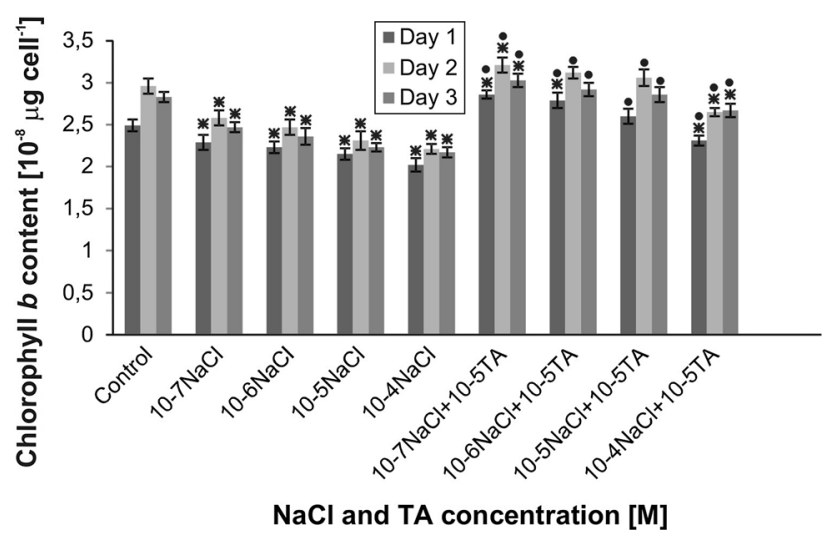

Fig. 3 The effect of traumatic acid $\left(10^{-5} \mathrm{M}\right)$ on chlorophyll $b$ content in $C$. vulgaris, treated with sodium chloride $\left(10^{-7}-10^{-4} \mathrm{M}\right)$. Data are the means of four independent experiments \pm SE. Asterisk indicates statistically different values compared to the control, filled circle indicates statistically significant differences between treatment with $\mathrm{NaCl}$ and the combined treatment $(\mathrm{NaCl}$ and $\mathrm{TA})$

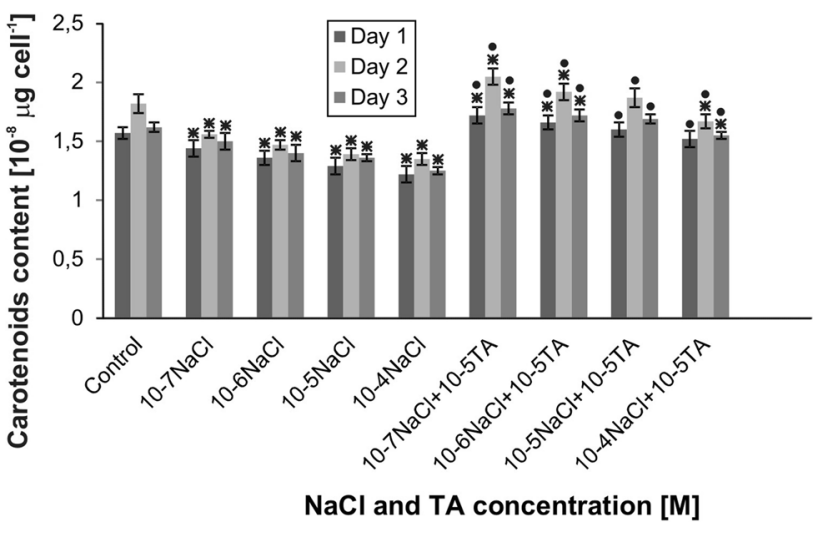

Fig. 4 The effect of traumatic acid $\left(10^{-5} \mathrm{M}\right)$ on carotenoids content in $C$. vulgaris, treated with sodium chloride $\left(10^{-7}-10^{-4} \mathrm{M}\right)$. Data are the means of four independent experiments \pm SE. Asterisk indicates statistically different values compared to the control, filled circle indicates statistically significant differences between treatment with $\mathrm{NaCl}$ and the combined treatment $(\mathrm{NaCl}$ and $\mathrm{TA})$

of alga cells. The highest number of cells was observed on the third day of the culture at $10^{-7} \mathrm{M} \mathrm{NaCl}$ together with TA.

The conducted studies also proved the stimulating effect of TA on the content of chlorophyll $a$ and $b$ in $C$. vulgaris cells treated together with $\mathrm{NaCl}$ (Figs. 2 and 3). Just as in the case of the number of cells, the influence of salt stress alone on $C$. vulgaris caused a decrease in the content of the analysed photosynthetic pigments. The greatest decrease, by $44.8 \%$, of chlorophyll $a$ occurred at a $\mathrm{NaCl}$ concentration of $10^{-4} \mathrm{M}$ whereas chlorophyll $b$ was decreased by $25.3 \%$ as compared to the control. The presence of TA in the cultures at $\mathrm{NaCl}$ concentrations $10^{-7}-10^{-4} \mathrm{M}$ eliminated the negative impact of salt stress on the content of the analysed pigments. The greatest increase in the content of

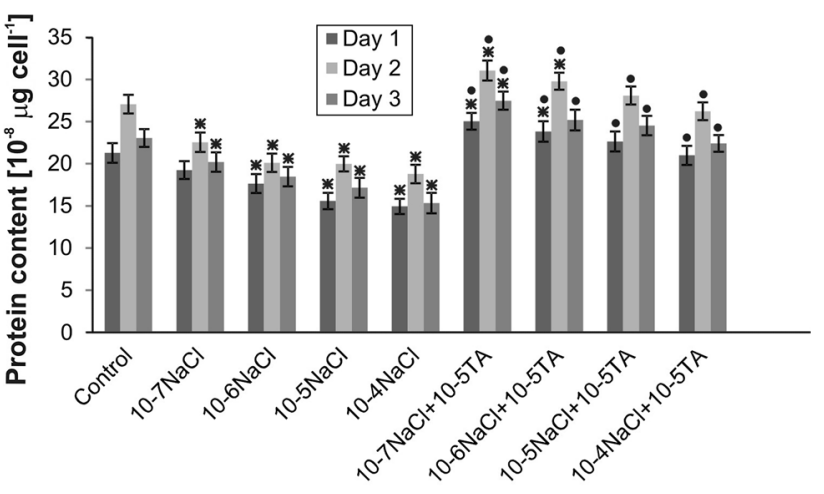

$\mathrm{NaCl}$ and TA conentration [M]

Fig. 5 The effect of traumatic acid $\left(10^{-5} \mathrm{M}\right)$ on protein content in $C$. vulgaris, treated with sodium chloride $\left(10^{-7}-10^{-4} \mathrm{M}\right)$. Data are the means of four independent experiments \pm SE. Asterisk indicates statistically different values compared to the control, filled circle indicates statistically significant differences between treatment with $\mathrm{NaCl}$ and the combined treatment $(\mathrm{NaCl}$ and $\mathrm{TA})$

chlorophyll $a$ and $b$ was observed on the second day of the culture at $10^{-7} \mathrm{M} \mathrm{NaCl}+10^{-5} \mathrm{M} \mathrm{TA}$.

The stimulating activity of TA on cultures of $C$. vulgaris treated with $\mathrm{NaCl}$ was also proved in the case of the content of carotenoids (Fig. 4). In cultures treated with $\mathrm{NaCl}$ alone, a decrease in content of the analysed pigments was observed. Our results showed that in comparison to the control, the content of carotenoids dropped by 10 and $23.8 \%$ at $10^{-7} \mathrm{M} \mathrm{NaCl}$ and $10^{-4} \mathrm{M} \mathrm{NaCl}$, respectively. The negative impact of salt stress on the content of carotenoids was inhibited by TA present in the culture. Cultures subjected to the influence of TA together with all $\mathrm{NaCl}$ concentrations exhibited an increase of carotenoid content. The highest value of carotenoids was observed on the second day of the culture at $10^{-7} \mathrm{M}$ of $\mathrm{NaCl}+10^{-5} \mathrm{M}$ of TA.

Based on the conducted analyses, it was also found that TA stimulated the content of proteins in the cells of C. vulgaris when treated together with $\mathrm{NaCl}$ (Fig. 5). In cultures under the influence of $\mathrm{NaCl}$ (applied at concentrations from $10^{-7}$ to $10^{-4} \mathrm{M}$ ), a decrease of cell protein content was observed. The greatest decrease was noted at the highest concentration of salt $\left(10^{-4} \mathrm{M} \mathrm{NaCl}\right)$ on the third day of the culture amounting to $33.4 \%$ in relation to the control. As in the cultures exposed to salt at concentrations $10^{-7}-10^{-4} \mathrm{M}$ together with $\mathrm{TA}$, an increase in the content of analysed metabolites was observed. The greatest increase occurred in the presence of $10^{-7} \mathrm{M} \mathrm{NaCl}+$ $10^{-5} \mathrm{M}$ TA on the third day of culture.

The performed studies showed that TA stimulated the content of monosaccharides in the cells of $C$. vulgaris in spite of treating a culture with $\mathrm{NaCl}$ (Fig. 6). In cultures growing under the influence of both $\mathrm{NaCl}$ in concentrations ranging from $10^{-7}$ to $10^{-4} \mathrm{M}$ and $\mathrm{TA}$, an increase of 


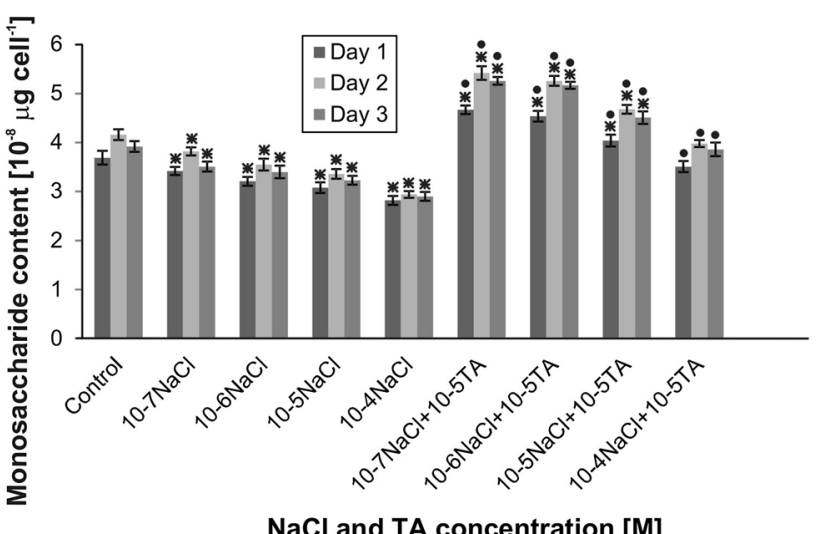

$\mathrm{NaCl}$ and TA concentration [M]

Fig. 6 The effect of traumatic acid $\left(10^{-5} \mathrm{M}\right)$ on monosaccharide content in $C$. vulgaris, treated with sodium chloride $\left(10^{-7}-10^{-4} \mathrm{M}\right)$. Data are the means of four independent experiments \pm SE. Asterisk indicates statistically different values compared to the control, filled circle indicates statistically significant differences between treatment with $\mathrm{NaCl}$ and the combined treatment $(\mathrm{NaCl}$ and $\mathrm{TA})$

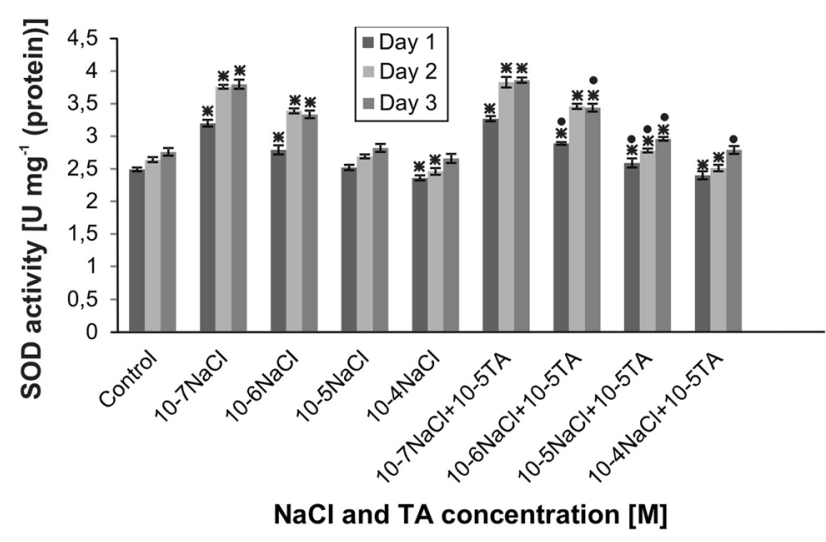

Fig. 7 The effect of traumatic acid $\left(10^{-5} \mathrm{M}\right)$ on SOD activity in C. vulgaris, treated with sodium chloride $\left(10^{-7}-10^{-4} \mathrm{M}\right)$. Data are the means of four independent experiments \pm SE. Asterisk indicates statistically different values compared to the control, filled circle indicates statistically significant differences between treatment with $\mathrm{NaCl}$ and the combined treatment $(\mathrm{NaCl}$ and $\mathrm{TA})$

monosaccharides content was detected. The highest value of monosaccharides was observed on the second day of the culture at $10^{-7} \mathrm{M}$ of $\mathrm{NaCl}+10^{-5} \mathrm{M}$ of TA. In those conditions, that parameter rose by $42 \%$ in relation to the sample treated with $10^{-7} \mathrm{M} \mathrm{NaCl}$. As for cultures treated with $\mathrm{NaCl}$ alone (without the addition of TA), they only displayed a decrease in the content of sugars with the increase in salt concentration. At $10^{-4} \mathrm{M} \mathrm{NaCl}$, an average drop of sugar level by $26.3 \%$ in comparison to the control was noted.

Furthemore, the experiments carried out proved the significant influence of salt stress on inducing SOD activity in C. vulgaris cells (Fig. 7). However, comparison of the SOD activity for each concentration of $\mathrm{NaCl}$ with that of the corresponding concentration of $\mathrm{NaCl}$ and $\mathrm{TA}$ proved that TA had no effect on SOD activity. Only, in cultures exposed to the activity of $10^{-5} \mathrm{M} \mathrm{NaCl}$ and a simultaneous treatment of alga cells with $10^{-5} \mathrm{M} \mathrm{TA}$, the activity of the enzyme was significantly higher than in the culture treated with $10^{-5} \mathrm{M} \mathrm{NaCl}$ alone. The highest SOD activity was observed at $10^{-7}$ and $10^{-6} \mathrm{M} \mathrm{NaCl}$. In comparison to the control conditions, the enzyme activity increased by 36.2 and $20.4 \%$ at $10^{-7} \mathrm{M} \mathrm{NaCl}$ and $10^{-6} \mathrm{M} \mathrm{NaCl}$, respectively.

\section{Discussion}

Studies on the effect of salt stress on plants are being carried out on a large scale as the response of plants to stress conditions may be considered at molecular, cellular, anatomical or morphological levels. Knowledge of the mechanisms involved both in the response of plants to salt stress and in developing tolerance is crucial for understanding the problem of salinity, which plays a significant role in the decline in agricultural productivity (Serrano and Rodriguez-Navarro 2001; Zhu 2003).

The influence of TA on plants is significant. Together with phytohormones, TA participates in the mechanisms of plant adaptation and defense, not only at injury sites but also when other environmental stress factors are involved, including high and low temperatures, osmotic stress, or pathogen attack (Sivasankar et al. 2000). The research conducted on a unicellular alga $C$. vulgaris proved that TA induced a significant increase in the number of algae cells and in the cells themselves as well as in the content of essential metabolites such as proteins, carbohydrates and photosynthetic pigments, in particular at a TA concentration of $10^{-5} \mathrm{M}$ (Pietryczuk et al. 2008).

The phytotoxicity of excessive amounts of $\mathrm{NaCl}$ is mainly reflected in the inhibited growth of plants. The present study showed that $C$. vulgaris treated with $\mathrm{NaCl}$ at concentrations $10^{-7}-10^{-4} \mathrm{M}$ was characterized by a smaller number of algae cells compared to the controls. This finding is consistent with data in literature according to which the salinity inhibits mitotic divisions, causes a slowdown in the elongation growth of cells, and, ultimately, reduces the rate of growth of leaves and roots (Munns and Tester 2008; Chen et al. 2012).

The conducted experiments also showed a stimulating effect of TA on the number of cells in $C$. vulgaris alga exposed to salt stress. These results are confirmed by other findings in literature showing that the addition of TA at $10^{-5} \mathrm{M}$ to a unicellular algae culture of $C$. vulgaris almost double the number of algae cells relative to the controls. It was also found that the greatest increase in the number of alga cells occurred during the first 3 days of 
the experiment, after which (between the fifth and seventh day of incubation) the stimulating activity of TA began to decrease (Pietryczuk et al. 2008).

Several environmental and anthropogenic factors can significantly modify the content of photosynthetic pigments in plants (Babu et al. 2011). Our experiments showed that $C$. vulgaris culture exposed to $\mathrm{NaCl}$ in a concentration range $10^{-7}-10^{-4} \mathrm{M}$ was characterized by a decrease in chlorophyll content. The inhibitory effect of $\mathrm{NaCl}$ on the biosynthesis of chlorophyll was also reported by Santos (2004). Her experiments have shown that sunflower leaves exposed to high concentrations of $\mathrm{NaCl}$ are characterized by a drastic decline of assimilation pigments, especially chlorophyll $b$.

The content of chlorophylls decreased with increasing $\mathrm{NaCl}$ concentrations but when simultaneously treated with TA it remained higher than in the samples treated with $\mathrm{NaCl}$ alone. The study has thus revealed that TA effectively reduces the negative effects of $10^{-7}-10^{-4} \mathrm{M} \mathrm{NaCl}$ on the biosynthesis and accumulation of chlorophyll in the cells of $C$. vulgaris. Also, previous studies carried out on the leaves of rice grown in the dark for a period of 3 days and treated with exogenous TA at concentrations of 45 and $90 \mu \mathrm{M}$ indicated that the compound had a significant impact on the growth and metabolism of the plants, for no decrease in chlorophyll pigments, which would occur under unfavorable environmental conditions, was observed in the experiment (Hung and Kao 1997). Based on that experiment and on the results obtained in the present study, it can be concluded that TA significantly slows down the aging process in plants and inhibits the degradation of photosynthetic pigments resulting from the influence of environmental stress factors, including salinity. According to literature data, $C$. vulgaris culture treated with TA at an optimum concentration $\left(10^{-5} \mathrm{M}\right)$ was characterized by an increase in the content of both chlorophyll $a$ as well as $b$, where the largest increase in the analyzed pigments was observed on the third day of the culture (Pietryczuk and Czerpak 2011).

As carotenoids play a very important role in the life of plants, this parameter was used in this study to investigate the effect of salt stress and salt in the presence of TA on the content of the pigments. $\mathrm{NaCl}$ at all test concentrations used in the present study caused a decrease of the concentration of carotenoids in C. vulgaris cells in comparison to the control culture. Previous studies related to salt stress carried out on maize showed phytotoxic effects of $\mathrm{NaCl}$ on plants. In those studies, maize treated with $\mathrm{NaCl}$ at a concentration of $50 \mathrm{mmol} \mathrm{dm}{ }^{-3}$ was characterized by a reduced content of carotenoids compared to the controls (Khodary 2004). The results also indicated that carotenoids, compared to chlorophylls, were less sensitive to salt stress.
Consistent with data existing in literature concerning the impact of TA on the growth and metabolism of $C$. vulgaris the addition of $10^{-5} \mathrm{M}$ TA to a culture of this unicellular algae increased carotenoid content (Pietryczuk et al. 2008). Therefore the increase in the content of these pigments in the cells of $C$. vulgaris under the influence of TA in cultures exposed to salt stress is probably one mechanism of adaptation counteracting the negative effects of $\mathrm{NaCl}$.

Salt stress also affects the intensity of photosynthesis by destabilizing protein complexes and the destruction of photosynthetic pigments, and thus contributes to reducing the content of sugars in the cells (Kłosowska 2010). This finding is confirmed by the present study in which exposure to $\mathrm{NaCl}$ significantly reduced the synthesis of monosaccharides in C. vulgaris.

In cultures treated with $\mathrm{NaCl}$ at concentrations in the range $10^{-7}-10^{-4} \mathrm{M}$ in the presence of TA, an increase in the content of monosaccharides exceeding that of the controls was observed. Based on the obtained results, it can be therefore concluded that TA reduces the negative effects of sodium and chloride ions and stimulates an increase in the content of monosaccharides. It is known from literature that they are important signal molecules involved in signal transmission leading to changes in gene expression in response to pathogens and injury, as well as to other environmental stressors. Furthermore, as signal molecules, monosaccharides also activate the genes encoding cyclins-the proteins involved in cell cycle regulation (Couée et al. 2006). Therefore an increase in the number of cells under influence of TA is probably indirectly induced by the increasing concentration of monosaccharides. It can also be stated that TA induces hydrolysis of sucrose and gluconeogenesis (Pietryczuk et al. 2008).

Similar to the previously discussed metabolites, it was found that $\mathrm{NaCl}$ had a negative effect on protein content in C. vulgaris cells, as well. This may have been caused by oxidative stress induced by the excess of $\mathrm{Na}^{+}$and $\mathrm{Cl}^{-}$ions in plant cells. Furthermore, in plants treated with $\mathrm{NaCl}$, the transport of $\mathrm{Ca}^{2+}, \mathrm{Mg}^{2+}, \mathrm{K}^{+}$, and other trace elements necessary for protein synthesis was lowered (Esechie et al. 2002).

The research presented here has also shown that TA induces an increase in cellular protein content despite the impact of $\mathrm{NaCl}$ ions. An increase in the accumulation of proteins in the cells of algae under the influence of $10^{-5} \mathrm{M}$ TA was also obtained by Pietryczuk et al. (2008). It is probably related to the role of TA in alleviating different kinds of stress including salt stress.

It is known from literature that as a consequence of each primary stressor, a state of so-called oxidative stress is brought about in plants. SOD is one of the major factors neutralizing reactive oxygen species. It catalyzes the reaction whereby oxygen from free radical forms is converted to 
hydrogen peroxide $\left(\mathrm{H}_{2} \mathrm{O}_{2}\right)$, a less reactive form (Bartosz 1997; Foyer and Shigeoka 2010). Dynamics of changes in the activity of SOD is therefore an excellent indicator of the level of stress in plants. In this study the factor inducing oxidative stress was $\mathrm{NaCl}$ applied at concentrations from $10^{-7}$ to $10^{-4} \mathrm{M}$ while one of the aims of the work was to determine the influence of TA on the degree of SOD activity under conditions of stress.

The present study showed that cells of $C$. vulgaris treated with $\mathrm{NaCl}$ at concentrations of $10^{-7}$ and $10^{-6} \mathrm{M}$ were characterized by an increase in SOD activity. Higher concentrations of salt $\left(10^{-5}\right.$ and $\left.10^{-4} \mathrm{M} \mathrm{NaCl}\right)$ caused the activity of SOD to decrease or remain at the level of the controls. From literature we know that at lower $\mathrm{NaCl}$ concentrations, the activity of SOD increases, while high concentrations of $\mathrm{NaCl}$ inhibit the activity of the enzyme (Song et al. 2006). Moreover, it is known that the changes in SOD activity in response to different salt concentrations depend on the test plant. Also studies with local wheat cultivars demonstrated that SOD activity was dependent on salt concentration. As a result, SOD activity increased in cv. Sardari with the increase of salt stress while in cv. Avland SOD showed constant activity at all salt stress levels (Esfandiari et al. 2007). The present study also showed that TA had no effect on inducing SOD activity in the cells of $C$. vulgaris exposed to salt stress. SOD activity in cells treated with TA in combination with $\mathrm{NaCl}$ did not differ significantly from the results obtained for cells treated with $\mathrm{NaCl}$ alone. Only with the exception of treatment with $10^{-5} \mathrm{M} \mathrm{NaCl}$ on the third day of culture, the cultures which were simultaneously treated with $10^{-5} \mathrm{M}$ TA showed a significant increase in SOD acvity when compared to the sample treated with $10^{-5} \mathrm{M} \mathrm{NaCl}$ alone. Moreover, the time-course changes of most parameters studied (pigmets, proteins, monosaccharides) in both controls and treated $C$. vulgaris cells showed a peak on the second day followed by a decrease on the third day except for SOD activity which showed a gradual increase with time. Similarly, in our previous work, the algae cells treated with TA demonstrated the highest increase of SOD activity on the third day of culture, by $60.7 \%$ up to $69.4 \%$, as compared with the control sample. Moreover NADPH oxidation catalysed by glutathione reductase, increases in the algae cells by $51.3-58.2 \%$ under the influence of TA on the third day of the experiment in comparison to the control culture (Pietryczuk and Czerpak 2011). Bowler et al. (1992) suggest that derivatives of nonsaturated fatty acids, in all probability TA as well, can assume the role of transmitters of signals to the nucleus and can induce the expression of SOD genes. Furthermore, stimulation of SOD activity can be positively correlated with the increase of glutathione reductase activity. It has been pointed out that for certain plant species, for instance tobacco, the increased concentration of reduced glutathione (product of reaction catalysed by glutathione reductase) induces an increase of mRNA content of cytosolic CuZnSOD (Żuchowski 1999). It cannot be excluded, though, that a similar dependence occurs in $C$. vulgaris treated with $\mathrm{NaCl}$ as well. Activation of genes encoding SOD by TA (directly or indirectly) may be the cause of the continuous increase in the activity of SOD, despite a decline in the concentration of other analyzed parameters on the third day of the experiment.

Summarizing the results obtained in this study, it may be concluded that TA at a concentration of $10^{-5} \mathrm{M}$ is a stimulator of cell growth and metabolism in $C$. vulgaris even when exposed to $\mathrm{NaCl}$. In relation to each of the studied parameters, TA to a greater or lesser extent showed activity neutralizing the adverse effects of salt stress.

Open Access This article is distributed under the terms of the Creative Commons Attribution License which permits any use, distribution, and reproduction in any medium, provided the original author(s) and the source are credited.

\section{References}

Babu MA, Singh D, Gothandam KM (2011) Effect of salt stress on expression of carotenoid pathway genes in tomato. J Stress Physiol Biochem 7:87-94

Bartosz G (1997) Oxidative stress in plants. Acta Physiol Plant 19:47-64

Beauchamp C, Fridovich I (1971) SOD improved assays and an assay applicable to acrylamide gels. Anal Biochem 444:276-287

Bohnert HJ, Shvelev A (1998) Plant stress adaptations-making metabolism move. Curr Opin Plant Biol 1:267-274

Bowler C, Van Montague M, Inez D (1992) Superoxide dismutase and stress tolerance. Annu Rev Plant Physiol Plant Mol Biol 43:83-116

Chen JH, Jiang HW, Hsieh EJ, Chen HY, Chien CT, Hsieh HL, Lin TP (2012) Drought and salt stress tolerance of an Arabidopsis glutathione S-transferase U17 knockout mutant are attributed to the combined effect of glutathione and abscisic acid. Plant Physiol J 158:340-351

Couée I, Sulmon C, Gouesbet G, El Amarani A (2006) Involvement of soluble sugars in reactive oxygen species balance and responses to oxidative stress in plants. J Exp Bot 57:449-459

Esechie HA, Al-Saidi A, Al-Khanjari S (2002) Effect of sodium chloride salinity on seedling emergence in chickpea. J Agron and Crop Sci 188:155-160

Esfandiari E, Shekari F, Shekari F, Esfandiari M (2007) The effect of salt stress on antioxidant enzymes activity and lipid peroxidation on the wheat seedling. Not Bot Hort Agrobot Cluj 35:48-56

Foyer CH, Shigeoka S (2010) Understanding oxidative stress and antioxidant functions to enhance photosynthesis. Plant Physiol 155:93-100

Howe GA, Schilmiller AL (2002) Oxylipin metabolism in response to stress. Curr Opin Plant Biol 5:230-236

Hung KT, Kao CH (1997) Senescence of rice leaves XXXV. Promotive effects of jasmonates. Bot Bull Acad 38:85-89

Khodary SEA (2004) Effect of salicylic acid on the growth, photosynthesis and carbohydrate metabolism in salt stressed maize plants. Int J Agric Biol 6:4-8 
Kłosowska K (2010) Plant responses to salinity. Kosmos 3-4: 539-549 (in Polish)

Li J, Nagpal P, Vitart V, Mcmorris TC, Chory J (1996) A role for brassinosteroids in light-dependent development of Arabidopsis. Science 272:398-401

Lowry OH, Rosebrough NJ, Farr AL, Randall RJ (1951) Protein measurement with the Folin phenol reagent. J Biol Chem 193:265-275

Munns R, Tester M (2008) Mechanisms of salinity tolerance. Ann Rev Plant Biol 59:651-681

Pareek A, Sopory SK, Hans J, Bohnert J (2011) Abiotic stress adaptation in plants: physiological, molecular and genomic foundation. Ann Bot 107:7-9

Pietryczuk A, Czerpak R (2006) Occurence, biosynthesis and biological activity of traumatic acid in lants. Post Biol Kom 33(4):591-601 (in Polish)

Pietryczuk A, Czerpak R (2011) Effect of traumatic acid on antioxidant activity in Chlorella vulgaris (Chlorophyceae). Plant Growth Regul 65:279-286

Pietryczuk A, Piotrowska A, Czerpak R (2008) The influence of traumatic acid on the growth and metabolite content of the green alga Chlorella vulgaris Beijerinck. Oceanol Hydrobiol Stud 37(1):3-15

Pirson A, Lorenzen H (1966) Synchronized dividing algae. Ann Rev Plant Physiol 17:439-458

Santos CV (2004) Regulation of chlorophyll biosynthesis and degradation by salt stress in sunflower leaves. Sci Hortic 103:93-99

Serrano R, Rodriguez-Navarro A (2001) Ion homeostasis during salt stress in plants. Curr Opin Cell Biol 13:399-404

Shulaev V, Diego C, Miller G, Mittler R (2008) Metabolomics for plant stress response. Physiol Plant 132:199-208
Siedow JN (1991) Plant lipoxygenase: structure and function. Ann Rev Plant Physiol 42:145-188

Sivasankar S, Sheldrick B, Rothstein SJ (2000) Expression of allene oxide synthase determines defense gene activation in tomato. Plant Physiol 122:1335-1342

Siyal AA, Siyal AG, Abro ZA (2002) Salt affected soils their identification and reclamation. J Appl Sci 2:537-540

Somogyi M (1954) Notes on sugar determination. J Biol Chem 195:19-23

Song F, Yang C, Liu X, Li G (2006) Effect of salt stress on activity of superoxide dismutase (SOD) in Ulmus pumila L. J Forest Res $17: 13-16$

Tester M, Davenport R (2003) $\mathrm{Na}^{+}$tolerance and $\mathrm{Na}^{+}$transport in higher plants. Ann Bot 91:503-527

Wang W, Vinocur B, Altman A (2003) Plant responses to drought, salinity and extreme temperatures: towards genetic engineering for stress tolerance. Planta 218:1-14

Wellburn AR (1994) The spectral determination of chlorophylls a and $\mathrm{b}$, as well as total carotenoids, using various solvents with spectrophotometers of different resolution. J Plant Physiol 144:307-313

Xiong L, Zhu JK (2001) Abiotic stress signal transduction in plants: molecular and genetic perspectives. Physiol Plant 122:152-166

Zhu JK (2001a) Plant salt tolerance. Trends Plant Sci 6:66-71

Zhu JK (2001b) Plant salt stress. In: eLS. Wiley, Chichester. doi:10. 1002/9780470015902.a0001300.pub2

Zhu JK (2003) Regulation of ion homeostasis under salt stress. Curr Opin Plant Biol 6:441-445

Żuchowski J (1999) Vegetable superoxide dismutases. Kosmos 48:87-93 